\title{
En el desierto todos son apaches: la identidad del norte en Tomóchic, de Heriberto Frías.
}

\section{In the desert everyone is Apache: the identity of the North in Tomóchic, by Heriberto Frías.}

\author{
Daniel Avechuco Cabrera \\ Universidad de Sonora (MÉXICO) \\ CE: avechucocabrera@gmail.com ID ORCID: 0000-0003-0969-9340 \\ Itza Estefanía Ceceña Coronado \\ Universidad de Sonora (MÉXICO) \\ CE: itza estefania@hotmail.com ID ORCID: 0000-0003-2498-1897
}

DOI: $10.32870 /$ sincronia.axxiii.n76.22b19

Recibido: $20 / 03 / 2019$

Revisado: $18 / 04 / 2019$

Aprobado: $12 / 05 / 2019$

\section{RESUMEN}

Tomóchic (1893), de Heriberto Frías, forma parte de los discursos culturales del siglo XIX que contribuyeron a construir el mapa de México en el imaginario social. En particular, la obra de Frías se inserta en la tradición de representaciones del norte de México, donde aparecen nombres como Manuel Payno, Ignacio Ramírez el Nigromante y Guillermo Prieto. A diferencia de estos, sin embargo, Heriberto Frías es un caso particular porque, si bien ratifica algunas de las premisas de la ciudad letrada sobre el mapa nacional, ofrece pinceladas sobre los territorios del norte que dialogan conflictivamente con el imaginario "canónico" de las regiones septentrionales. Por lo tanto, algunas partes de Tomóchic están construidas sobre la tensión que produce el contacto de dos imágenes opuestas. Por un lado, hallamos entreverados en la trama los rasgos que una mirada centralista- 
nacionalista típica del liberal finisecular del XIX le atribuiría al sujeto y el espacio norteños; pero, por otro, el compromiso social de Heriberto Frías lo lleva a aproximarse al sujeto del norte con el objeto de humanizarlo, y pese a los obstáculos culturales y epistemológicos, perfila, si bien tímidamente, una identidad norteña.

Palabras clave: Novela mexicana decimonónica. Memoria regional. Mapa nacional.

\section{Abstract:}

Tomóchic (1893), by Heriberto Frías, forms part of the cultural discourses of the 19th century that helped to build the map of Mexico into the social imaginary. In particular, the work of Frías is inserted in the tradition of representations of northern Mexico, where names such as Manuel Payno, Ignacio Ramírez the Necromancer and Guillermo Prieto appear. Unlike these, however, Heriberto Frías is a particular case because, although it ratifies some of the premises of the ciudad letrada on the national map, it offers small strokes on the northern territories that dialogue conflictively with the "canonical" imaginary of the northern regions. Therefore, some parts of Tomóchic are built on the tension produced by the contact of two opposing images. On the one hand, we find interspersed in the plot the features that a centralist-nationalist look typical of the late eighteenth-century liberal would attribute to the northern subject and space; however, on the other, the social commitment of Heriberto Frías leads him to approach the subject of the north in order to humanize it, and despite the cultural and epistemological obstacles, traces, though timidly, a northern identity.

Keywords: Nineteenth-century Mexican novel. Regional memory. National map.

\section{Bárbaros en los márgenes de la nación}

Como señala Roger Bartra en El salvaje ante el espejo (1992), en la historia de Occidente ha existido una clara tendencia a la autodefinición identitaria y cultural a partir de la invención de una otredad que, por contraste, proporciona la silueta ideal del yo. En el imaginario de la Grecia presocrática y mítica, esa entidad se caracterizaba por una fisonomía humanoide y bestial, cuando no 
directamente monstruosa, y una conducta impropia de los preceptos de la civilidad. ${ }^{1}$ Violencia en su más diversa morfología, sexualidad desenfrenada y ruptura de los más elementales principios de la convivencia: todo esto encarnan esos engendros que moran en zonas remotísimas, apartadas de los grandes centros culturales (López, 2013). En la Grecia posthomérica, el Otro adquiere rasgos humanos, aunque continuará siendo un salvaje, una condición determinada por la ocupación del espacio marginal: "Lugares que van desde remotas islas, pasando por altas e inaccesibles cumbres, selvas profundas e, incluso, desiertos e infinitas llanuras" (Muñoz, 2008, p. 157). Desde ese momento, la dicotomía espacio urbano-espacio no urbano se convierte en uno de las bases para la asignación de un estatus ontológico-epistemológico: en la ciudad se afincan la razón, el orden y la ley; fuera de ella, la irracionalidad, la anarquía y los imperativos de la naturaleza. Durante el medievo, esta dicotomía tendrá continuidad y dará pie a la invención de un sujeto salvaje en el que confluirán el modelo clásico y los prejuicios que sobre las creencias y prácticas paganas del sector rural proporciona el imaginario cristiano; en síntesis, el Otro entrará en contacto con las fuerzas demoníacas. $^{2}$

Constituye ya un lugar común señalar que la concepción europea de civilización, cifrada en el esquema que se simplifica en el párrafo anterior, fue determinante para la construcción de la otredad americana; basta recordar las ilustraciones de Caspar Plautius o Theodore de Bry sobre las supuestas costumbres caníbales de las culturas del Nuevo mundo. Esta clase de visiones sobre el sujeto americano está mediada por el profundo etnocentrismo de la mentalidad europea; sin embargo, los prejuicios del recién llegado no se establecieron en la mirada arbitrariamente, sino que fueron alimentados por la extrema dificultad que supuso colonizar determinadas regiones, ya fuera por la tenacidad de algunas comunidades o por la hostilidad de geografías indomables, y muchas veces por la combinación de ambas cosas. Estos conflictos, aunados a preconcepciones de

\footnotetext{
1 "When archaic poetry defines the Greeks' way of life-their adherence to laws, their rituals and sacrifices and strictly defined taboos, their patriarchal social structure-it is not in contrast with the discrepant mores of non-Greek heroes, but with the anarchy and violence, sacrilege and gynaecocracy of the "supernatural barbarians", the Giants, Centaurs, Cyclopes, and Amazons" (Hall, 1989, p. 54).

2 Para ahondar en este tema, véase "Etnografía del salvaje medieval," el cuarto capítulo de El salvaje ante el espejo (1992), de Roger Bartra.
} 
tradición añeja, propiciaron un imaginario negativo de ciertos territorios americanos que sobrevivió al paso de los siglos y al surgimiento de las repúblicas y su retórica nacionalista (Giménez y HéauLambert, 2007), en la cual el factor autóctono, humano o espacial, tuvo un papel central.

Desde el inicio, la historia del extremo septentrional de la América española, en especial Nueva Navarra y Nueva Vizcaya, estuvo condicionada por la hostilidad de su topografía y por la belicosidad de sus moradores, agrestes, tercos, supersticiosos, borrachos, indecentes y refractarios a las bondades de Dios, como los describiría el padre alemán Juan Nentvig (1971) en uno de sus informes (pp. 120-123). Esta historia explica el divorcio cultural que hubo entre los territorios norteños de México y el centro del país durante todo el siglo xIX y parte del xx (Rajchenberg y HéauLambert, 2007), lo cual hace evidente que no es lo mismo una nación entendida en términos estrictamente político-administrativos que como un cúmulo de ideas, símbolos y sentimientos acerca de un lugar. Un país propende a condensar en su interior una serie de zonas con memorias regionales propias, lo cual pone en predicamento la homogeneización, dinámica tiránica pero imprescindible en la formación y consolidación de los Estados-nación tal cual se entendieron en un primer momento. Una de las estrategias para homogeneizar la patria es, precisamente, la construcción simbólica de una espacialidad nacional que concentre la mayoría de los atributos que se le supone al país. Dicha construcción es resultado no, por supuesto, de la convergencia de las distintas geografías regionales, lo que redundaría en una inoportuna heterogeneidad, sino de la mutilación:

Ciertos territorios son hermanados, otros son excluidos o escasamente emparentados. Entre todos, hay uno privilegiado. Es el espacio-sagrado, el "corazón" de la nación, la "cuna" de la patria, tierra de los ancestros; en suma, el epítome de la nacionalidad. En él hay una densidad simbólica que contrasta con el relativo páramo de significados de otros. Desempeña, en este sentido, el papel de una metonimia territorial mediante la cual ese territorio simboliza toda la nación. En términos más estrictos, la patria se condensa ahí. ¿Hasta dónde llega la región focal a simbolizar el territorio en su conjunto? Del alcance de esta operación depende que ciertas regiones sean hermanadas y otras permanezcan como 
hermanastras o de plano excluidas de la construcción identitaria. (Rajchenberg y HéauLambert, 2012, p. 42)

En el caso de México, el territorio que desde la perspectiva de la intelligentsia de la naciente república agrupaba las virtudes de la nación era el altiplano. Y es que aparte de que poseía una topografía fértil y bucólica, en el centro se había cocinado el país en términos de procesos históricopolíticos. Así, el norte fue desdeñado, lo cual, aunado a la fuerte memoria regional norteña, propició un distanciamiento entre ambas regiones (Rajchenberg y Héau-Lambert, 2005, 239).

Como han señalado tantos especialistas en el tema, la memoria regional del norte es indisociable de su larga historia de lucha contra ciertos grupos indígenas de naturaleza nómada o seminómada, en especial contra comanches y apaches. Ese último grupo, además, tuvo un peso profundamente simbólico, pues la figura del apache fue fundamental por cuanto que su obstinada y muy sanguinaria presencia sirvió desde el principio de la Colonia como elemento generador de orgullo y cohesión grupal (Almada, Lorta, Contreras y Reyes, 2015, p. 266). En Crónicas de un país bárbaro, Fernando Jordán (1981) relata cómo los habitantes de algunos pueblos de Chihuahua se congregaban para atestiguar el retorno triunfal de las partidas de vecinos que, legitimadas por las contratas de sangre, habían dejado la comunidad con el propósito de buscar cabezas apaches ( $p$. 246). Con el transcurso del tiempo, estas reuniones públicas espontáneas -incitadas por un ánimo curioso, sí, pero también por un impulso solidario-, junto con las anécdotas sangrientas que los cazadores de cabezas salvajes recolectaban en su aventura por el desierto, habrían de coadyuvar a la gestación de una identidad propia, ajena a los conflictos burocráticos del Centro, donde las autoridades se hallaban "más preocupadas por sobrevivir y mantenerse en Palacio Nacional que por la suerte de regiones tan aparatadas" (González y León, 2000, p. 186). Como tantos estudiosos han insistido, esta identidad se caracteriza por una tendencia a la autonomía política, un marcado individualismo y, muy especialmente, una relación estrecha con la violencia, como apunta Fernando Jordán: 
la escuela del norte fue más cruel y más dura que en cualquier otra parte del país, y es posible que por tal, las generaciones posteriores llevaran en su espíritu un gen de agresividad y de afán de lucha, merced a la herencia de caracteres adquiridos que niegan los fisiólogos. (1981, p. 161).

Este espíritu agresivo, que Jordán explica partiendo de la historia regional de Chihuahua, sin duda fue uno de los principales promotores del concepto que del sujeto y el espacio norteños han tenido las élites culturales y políticas del centro del país. La violencia equivale al atributo por antonomasia del Otro, de modo que, como bien señala Jorge Chávez (2007), la perspectiva centralista ha tendido a asimilar al norteño con el apache (p. 175). Esta asimilación es fomentada, entre otras cosas, por las condiciones excepcionales en que se daba la formación de las comunidades septentrionales:

Las unidades familiares a mediados del siglo XIX en Chihuahua estaban lejos de ser hogares unidos por el parentesco, debido a que en ellas, al igual que en Nuevo México, se recogían niños abandonados y cautivos de guerra. Las epidemias, tanto en la época colonial como en el México independiente, jugaron un papel importante en el desarrollo poblacional del estado de Chihuahua porque, al mismo tiempo que causaban bajas entre los indios indómitos, hacían necesarios nuevos aportes demográficos externos. Así, se reducía a los bárbaros al cautiverio para sustituir a los muertos. (Cramaussel, 2015, pp. 218-219).

Así pues, el perfil aguerrido de los habitantes de algunas regiones del norte, sobre todo aquellas que se distinguen por la presencia tenaz de tribus apaches, y la costumbre de asimilar "barbaros" para conseguir el equilibrio demográfico contribuyeron a que en el imaginario centralistanacionalista, las características históricamente atribuidas a los apaches fueran extendidas al sujeto norteño en general, en especial al que se hallaba lejos de los sectores urbanos. Descendientes de colonos militares, criollos, mestizos o apaches: desde el ángulo centralista, todos estaban cortados con un patrón similar, el que determinaba el espacio yermo, salvaje y casi sin límites, que moldea el 
carácter, que lo retrotrae a una especie de barbarie permanente, que lo vuelve reacio a la vida "civilizada"3.

La centuria decimonona mexicana -hispanoamericana en general- se caracteriza, entre muchas otras cosas, por la necesidad de las élites de "configurar una Nación, de otorgar soberanía a los Estados, con lo cual este problema se enlaza íntimamente con la reflexión sobre el territorio y sus límites" (Moyano, 2000-2001, p. 51). En esta tarea de esbozar y apuntalar el mapa nacional y de reflexionar acerca de sus límites, la literatura ha cumplido un papel muy importante en tanto discurso productor, reproductor y difusor de imágenes que robustecen el imaginario de un país o contribuyen a modificarlo. Tomóchic (1893), de Heriberto Frías, constituye un caso particular porque a la vez que ratifica algunas de las premisas del discurso de la ciudad letrada sobre el mapa nacional, ofrece ciertas pinceladas sobre los territorios del norte que dialogan conflictivamente con el imaginario "canónico" de las regiones septentrionales.

Así, algunas partes de la obra están construidas sobre la tensión que produce el contacto de dos imágenes opuestas. Por un lado, hallamos entreverados en la trama los rasgos que una mirada centralista-nacionalista típica del liberal finisecular del XIX le atribuiría al sujeto y el espacio norteños; pero, por otro, por algunos resquicios de la novela asoman de cuando en cuando imágenes que parecen reclamar la presencia de una comunidad orgullosa de pertenecer a la periferia, al territorio sin patria. Es decir, acaso sin buscarlo Tomóchic proyecta un universo escindido, un universo en el cual asistimos al derrumbamiento del isomorfismo nacional (Gupta y Ferguson, 2008, p. 235) tan caro a los nacionalistas mexicanos de finales del siglo XIX.

\section{Tomóchic: vislumbres de una identidad norteña}

\footnotetext{
${ }^{3}$ Como bien señalan Rajchenberg y Héau-Lambert (2008), en el discurso nacionalista hispanoamericano del siglo XIX, el desierto representa mucho más que una superficie problemática:

La alteridad no se fundamenta en los rasgos atribuidos a los miembros de otro Estado-nación, sino que se define respecto a habitantes del mismo Estado territorial, recluidos a la condición de bárbaros Estos son los habitantes del desierto porque éste es un territorio no civilizado. Es el "desierto de las almas", decía Vasconcelos en los primeros años del siglo XX cuando tuvo que recorrer el norte de México, porque en él sentía la extranjeridad del lugar como si estuviera no sólo en otro país, sino en un no-lugar. (p.182)
} 
Muchas de las imágenes literarias sobre la región septentrional de México fueron resultado del viaje. Este aserto es aplicable a Manuel Payno, cuyas experiencias en el norte del país salpicaron su obra ficcional, como ciertos pasajes de Los bandidos de Río Frío, algunos de sus cuentos, como "La víspera y el día de la boda", y algunos de sus artículos de costumbres, como "Monterrey" y "El río Bravo del norte". Hay que recordar también las crónicas viajeras de Ignacio Ramírez el Nigromante, donde deja constancia de su paso por Sinaloa, Sonora y Baja California Norte; o las de Guillermo Prieto, donde ofrece vívidas estampas de Zacatecas y Querétaro. En estos casos, el viaje permite el contacto entre el Centro, cuyos valores porta el viajero, y el Norte. Este contacto, sin embargo, no deriva en un diálogo auténtico, en un diálogo con tensión, pues los valores del norte lógicamente están siempre tamizados por la perspectiva letrada; en ese sentido, podría decirse que los viajes de Payno, Ramírez y Prieto no abren interrogantes, sino que solo corroboran preconcepciones.

Tomóchic, de Heriberto Frías, se inserta en esta tradición de representaciones verbales del norte de México a partir del desplazamiento espacial desde el centro; sin embargo, a diferencia de las obras mencionadas en el párrafo anterior, en la escritura de Tomóchic también es fundamental la guerra, pues esta propicia el contacto con el Otro en muchos sentidos, y los propósitos de denuncia que determinó su proceso creativo, que obligan al narrador a buscar estrategias para explorar la realidad desde la perspectiva tomochiteca. Así, el entramado textual de la obra revela un silencioso conflicto entre los valores letrados, concretados en la diégesis a través de la figura de Miguel Mercado, alter ego de Heriberto Frías (Davobe, 2004, p. 356), y una embrionaria subjetividad norteña, aunque claramente tamizada por la visión dominante, como no puede ser de otra manera en una obra decimonónica.

Al margen de su espíritu crítico y acusatorio de las prácticas tiránicas y represoras del Estado, Tomóchic necesariamente parte del imaginario sobre el Norte forjado en las letras del Centro. De esta manera, al menos en principio la obra sigue el camino que trazaron los discursos anteriores. Esto es muy claro en la configuración del espacio, que se ciñe sin más a la "poética" propuesta por las élites de la Ciudad de México: la sierra es "abrupta, colosal y salvaje" (Frías, 2005, p. 145), el Cerro de la Cueva contempla "como un tigre sentado sobre su grupa" (Frías, 2005, p. 
145), Tomóchic es "una villa que se había vuelto loca" (Frías, 2005, p. 35), "un pueblo semisalvaje" (Frías, 2005, p. 90) y “oscuro" (Frías, 2005, p. 31) que acusa una "siniestra soledad tenebrosa" (Frías, 2005, p. 149) y que expele calientes ráfagas “de fanatismo religioso" (Frías, 2005, p. 31). En la configuración del espacio, como podemos ver, se sigue al pie de la letra los muy conocidos recursos de la animalización y la adjetivación hiperbólica, por lo que se transparenta un Miguel Mercado en función de turista que percibe el entorno mediante el cristal de sus valores citadinos. En tanto inigualable microcosmos del bronco norte, Tomóchic parece no dejarse capturar por la letra si no es recurriendo a los esquemas de representación que labraron los antecesores de Heriberto Frías.

Más de lo mismo podemos decir de la construcción de los tomochitecos, descritos como "hombres incultos" (Frías, 2005, p. 162), "demonios" (p. 2), "terribles" (p. 6), como un "puñado de bárbaros y estúpidos hijos de las rocas de Chihuahua" (p. 101). La adjetivación y los epítetos parecen extraídos directamente de las páginas de El Siglo Diecinueve, El Faro, El Nacional y La Patria, algunos de los periódicos más importantes de la Ciudad de México que les dieron cobertura a los sucesos de Tomóchic y que respaldaron la versión del Estado, según la cual los tomochitecos, tremendamente ignorantes, estaban siendo espoleados por el clero ${ }^{4}$. Siempre que el narrador de Tomóchic se propone describir a los habitantes de la sierra, se le impone la tradición retórica sobre el bárbaro del norte, aun cuando el objetivo sea poner al descubierto sus virtudes. A lo sumo, consigue estampas ambivalentes, pletóricas de opuestos, de virtudes y defectos de acuerdo con el horizonte letrado. Esto ocurre incluso cuando Miguel Mercado ya se ha estrellado contra la realidad y ha modificado su visión de mundo, como podemos corroborar en una de los últimos retratos de los tomochitecos, justo después de que caen abatidos cerca del final de la obra:

¡Oh! Flamígera extinción de los aduares de la fanática tribu de montañeses, soberbios en su ignorancia tremenda y salvaje, hijos bravíos de las sierras, aguiluchos encaramados en sus nidos formidables, obstinados en el capricho bárbaro de su orgullo supremo; que desafiaran la muerte con un épico desdén y una colosal sonrisa trágica que llegaría a ser sublime y

\footnotetext{
${ }^{4}$ Como sea, hubo periódicos que rehuyeron de los prejuicios y de la línea marcada por el Estado a la hora de abordar los sucesos de Tomóchic. Fue el caso de El Diario del Hogar, periódico de espíritu contestatario con una mirada más crítica de los acontecimientos y que, por ello, entró en polémicas con la prensa capitalina afín al gobierno de Porfirio Díaz.
} 
estupenda cuando se hiciese fúnebre. ¡Oh! ¡Tomóchic... ¡Oh bárbaro y épico Tomóchic! ¡Oh! fenecido pueblo de halcones serranos, de jóvenes águilas solitarias, encastilladas en los baluartes altísimos de las fragorosas montañas... iTu inaudita pujanza, tu delirante y pueril ensueño de absurda libertad salvaje en el imperio inmenso de las selvas y de los montes [...] tu sangre y la sangre generosa, hermana, que harás derramar hasta que muera el último de los tuyos, te hacen grande y extraño con una tristísima y lamentable grandeza...! (Frías, 2005, p. 147)

La percepción ortodoxa del espacio y los sujetos norteños permea incluso las partes de la obra que podríamos tildar de novelescas por estar un tanto desvinculadas de la resistencia de Tomóchic. Me refiero, específicamente, a la trama amorosa, esa nota anacrónica que discuerda del estilo realista y a menudo naturalista que domina en los pasajes de la campaña militar, que son mayoría. ${ }^{5}$ Si bien funciona como una suerte de paréntesis, la configuración de Julia, la serrana de la que se enamora Miguel Mercado, responde a los patrones propios de la organización del mundo del binomio civilización-barbarie. Y es que a través de Julia, Tomóchic subraya las diferencias que el narrador anteriormente ha establecido entre la vida de la sierra y la de la ciudad. El texto de alguna manera plantea que la experiencia de Julia en el ambiente citadino modificó su ser y su estar en el mundo, aunque no arrancó de raíz algunos de los rasgos que comparte con el resto de los tomochitecos. El narrador la describe así:

aquella criatura de precoz inteligencia, natural vivacidad y sensibilidad exquisita, no debía haber nacido en aquel ambiente de locura hostil en que se agitaba un pueblo semisalvaje del que no tenía sino el supremo heroísmo y el raro valor de saber soportar dignamente la adversidad, el triste heroísmo de saber morir[...]. (Frías, 2005, 67).

\footnotetext{
${ }^{5}$ Dice Emanuel Carballo: "superpone tres maneras de encarar en literatura el mundo y el hombre: la romántica, la realista y la naturalista" (citado en Sandoval, 2001, p. 275). Daniel Orizaga (2008) concuerda: "Tomóchic es un documento inmejorable para observar las transiciones entre corrientes literarias como el Romanticismo de principios de siglo, el Realismo -o mejor, en el caso de Frías, Naturalismo- y el Modernismo" (p. 199). Catherine Raffi-Béroud (2001), por su parte, considera que la novela tiene una "peculiar tonalidad romántico-naturalista-premodernista" (p. 284).
} 
Julia habita la ciudad por un tiempo, pero se ve en la necesidad de regresar a su pueblo de la sierra, razón por lo cual su proceso de civilización se ve interrumpido. El contacto con la vida moderna le ha permitido aprender a leer y desarrollar ciertas capacidades intelectuales -exclusivas de la ciudad, de acuerdo con la perspectiva ilustrada- que la llevan a comprender la sinrazón del comportamiento de su gente; sin embargo, ese aprendizaje fue insuficiente cambiar irreversiblemente su ontología: la superstición, el ambiente violento, el recato y los sortilegios del espacio salvaje pueden más que la brisa civilizadora. Julia termina aceptando su realidad inmediata: Tomóchic codifica esto en términos románticos, pero sabemos que debajo de ese velo se oculta el determinismo positivista.

Así pues, aun con la voluntad autoral de ofrendar un cuadro crítico y desmitificador acorde con el programa denunciatorio de la obra, Tomóchic no consigue evitar del todo el estereotipo cuando se dispone a construir una imagen "realista" del norte; es como si dichos estereotipos fueran parte de la constitución del lenguaje periodístico-literario del que echa mano el letrado finisecular. Con todo, la "inquietud reporteril" (Sandoval, 2001, p. 267) y el compromiso social de Heriberto Frías lo llevan a aproximarse al serrano con el objeto de humanizarlo. Pese a los obstáculos culturales y epistemológicos que hay en el camino, esta voluntad autoral abre resquicios a través de los que se filtran con frecuencia la perspectiva y los valores del norteño. Ya desde los primeros compases de la obra, Miguel Mercado explora el perfil aguerrido de los tomochitecos apelando no a los costumbrados presupuestos positivistas, sino a la historia regional:

Los pueblecillos de la Sierra Madre, al oeste de Chihuahua, vivían en constante alarma por las excursiones bárbaras de los apaches [...] Todo el mundo allí tenía su carabina o su fusil, que los montañeses descolgaban a cada momento para organizar batidas" (Frías, 2005, p. 31; las cursivas son mías).

Este fragmento matiza la percepción letrada de los tomochitecos según la cual la violencia era inherente a su naturaleza. Si desde una mirada externa se asumía que no había diferencias sustanciales entre los tomochitecos, las comunidades indígenas de la región y los apaches en la 
medida en que todos estos grupos mostraban el mismo perfil violento, la breve pero significativa exploración de la memoria y la identidad regionales que lleva a cabo Tomóchic contribuye a desarticular este prejuicio basado en la generalización. Ciertamente los colonos de los que descienden los tomochitecos debieron especializarse en las artes de la violencia con tal de consolidarse como comunidad (Alonso, 1995, p. 21), pero gran parte de la identidad serrana se basa en la diferenciación con respecto al Otro "autóctono", en particular el apache.

Esta primera aproximación a la cultura tomochiteca, fruto del saber generalizado acerca de los pueblos de la sierra chihuahuense, constituye solamente un preámbulo: después Miguel Mercado tendrá la oportunidad de participar como escucha de la tradición oral de la región, lo cual sucede en el capítulo XVI, "Evocación: la campaña contra los apaches". Miguel es designado para cubrir la retaguardia de la tropa, donde se encuentra con dos locales que fungen de guía. Uno de ellos es un anciano, una suerte de repositorio de la memoria de su pueblo, que le cuenta al joven subteniente algunas de las campañas contra los apaches ${ }^{6}$. Daniel Chávez $(2006$, p. 76) interpreta este pasaje como una apropiación letrada de la memoria regional; sin duda hay algo de esto, dado que Tomóchic no le cede completamente la voz al serrano, pero la mera inclusión de este capítulo supone un compromiso con el Otro, al que se busca conocer abandonando, aunque sea transitoriamente, los valores del Centro. Miguel y el anciano guía caminan "juntos por entre la maleza" (Frías, 2005, p. 162) y conversan con "camaradería cordial” (p. 163); como se ve, existe una momentánea relación de horizontalidad entre el individuo que viene de la Ciudad de México y el habitante de las regiones del norte. Esta relación es capital, pues propicia el entendimiento que hace falta para explorar subjetividades alternativas. Nótese cómo el espacio norteño queda tamizado por el recuerdo del lugareño, cuyas palabras arroban a Miguel Mercado:

El vibrante anciano hablaba con tanto relieve y color, que Miguel, enternecido, tuvo la visión clara de aquel cuadro.

\footnotetext{
6 "El 25 de mayo de 1849, la legislatura local [de Chihuahua] aprobó la ley que autorizaba la compra de prisioneros apaches o de sus cabelleras por medio de contratos y que fue conocida como ley de cabelleras, ley quinta o, sin mayores contemplaciones, como las contratas de sangre" (González y León, 2000, p. 174).
} 
Veía pasar, en la mañana primaveral, espléndida de sol, tibia aún, bajo el dosel de raso azul oscuro del hermoso cielo de Chihuahua, por la calle animada repentinamente, el desfile de la cabalgata heroica.

Veía los valientes que regresaban victoriosos de la feroz campaña contra los bárbaros apaches.

En las banquetas, la gente del pueblo forma valla; las familias asoman a las ventanas; los tenderos han soltado el mostrador para salir a las puertas de sus casas, y en el ambiente claro vibra el jubiloso repique de la esquila mayor de la Parroquia.

Aquella brava caballería desfila lentamente, de a cuatro de fondo. Sombreros anchos sobre rostros ennegrecidos de barbas hirsutas; blusas grises o chaquetones de cuero, pantalones de gamuza amarilla y teguas altas; monturas improvisadas con pieles de venado y de animales de la Sierra... (Frías, 2005, p. 67)

El cambio de tiempo verbal en el último párrafo del fragmento, del pretérito al presente, deja muy claro que Miguel Mercado vive la experiencia local a través de las palabras del anciano. Es manifiesta, además, la recurrencia del verbo ver. O sea, el protagonista de Tomóchic experimenta la memoria regional mediante el discurso del guía; este, pues, es un puente entre dos culturas que resultan irreconciliables porque entre ellas hay un abismo histórico y -más importante todavíaporque una de ellas, la letrada, menosprecia a la otra incluso hasta la negación. Evidentemente, en la memoria regional el tomochiteco ocupa el lugar del sujeto y el Otro es el apache, cuya violencia carece de todo sentido; y es que no debemos olvidar que la construcción del Otro no es un fenómeno cultural privativo de los distintos procesos de colonialismo occidental. Las propias comunidades subalternas, al margen de su sitio en las relaciones poder, fundamentan parte de su especificidad identitaria en una alteridad, pues todo grupo social, en mayor o menor medida, "tienen en común un punto de partida etnocéntrico" (Barabas, 2000, pp. 9-10). En el caso de la cultura tomochiteca, su componente etnocéntrico se expone en la configuración del apache, el cual es reducido a un agente del caos. La articulación de su memoria, en otras palabras, desplaza la frontera hacia arriba, desde donde emergen los temibles apaches, y en consecuencia los 
tomochitecos adquieren toda la subjetividad que el discurso de las élites le ha negado al hombre del norte. Como se advierte en el fragmento, esta subjetividad no queda anulada por las prácticas violentas; al contrario: la violencia que se deriva de la autodefensa y de las compañas de vecinos contra los apaches convive sin problemas con un sistema de valores, que Ana María Alonso (1995) expone en los siguientes términos:

From the serrano point of view, the pueblo was imagined as an egalitarian community of kin and vecinos whose relations were regulated by the moral and sacred norms and values of a code of honor. The self was viewed as embedded in a nexus of social relations. Honor depended on the fulfillment of obligations and responsibilities to those with whom on was linked by ties of blood and localty. (p. 208)

Entre los tomochitecos, pues, la violencia exogámica, dirigida ya sea a los apaches, ya a las fuerzas federales, es la exteriorización de un compromiso con la comunidad, un compromiso de protección mutua. Por eso las rememoraciones del anciano no despiden dolor, trauma, sino un aroma a orgullo, a sentimiento de pertenencia. Y si en la evocación hay ciertos subrayados de la violencia, es por la intromisión de la perspectiva de Miguel Mercado, cuya formación y cuyos valores obligan al narrador, que se sitúa en los ojos de aquel, a poner de relieve lo que en la consciencia letrada del protagonista resulta necesariamente escandaloso: "Y aquella cabalgata transformábase en un ambulante y espesísimo bosque horrible de melenas ensangrentadas y negras... Un estremecimiento de hondo pavor flotaba en torno" (Frías, 2005, p. 68; las cursivas son mías). La línea marcada en cursivas claramente entra en contradicción con el ambiente jubiloso presente en el fragmento comentado arriba, donde se describe el regreso triunfal de la partida de cazadores de cabelleras apache. Esta contradicción deja entrever la presencia de dos visiones amalgamadas en el discurso de ese capítulo, la de Miguel Mercado y la del anciano, que entran en tensión. Esta relación tensa es una forma implícita no solo de dar cuenta de la cosmovisión norteña, sino también de proveerla de cierta legitimidad, puesto que no habría tensión si dicha cosmovisión no tuviera peso. A la vista de esto, tiene mucho sentido que los federales griten “iViva la Nación unida!” (Frías, 2005, 
p. 153) a mitad de las batallas; este grito simboliza la guerra discursiva de un gobierno que, como apunta Horacio Legrás (2017), había perfeccionado el arte de invisibilizar la totalidad nacional (p. 25).

Es en gran parte gracias al delineamiento -esquivo, sutil, tímido- del perfil del norteño, que podemos considerar que Tomóchic una obra portadora de modernidad: al humanizar al tomochiteco y proyectar la realidad, aunque sea de forma transitoria, a través de su perspectiva y sus valores, el texto de Heriberto Frías anticipa la heterogeneidad cultural e identitaria del país que casi veinte años después pondrá al descubierto definitivamente el cataclismo de la Revolución mexicana. Además, la obra cuestiona, acaso sin proponérselo, el discurso positivista al ubicar la violencia popular del norte dentro de un marco que la explique cultural e históricamente, un marco en el que se debilitan las premisas deterministas.

\section{Conclusiones}

Tomóchic es resultado de la combinación de fabulación novelesca, espíritu denunciatorio y experiencia de Heriberto Frías como parte del ejército que combatió contra los tomochitecos. Esta combinación explica la articulación de un discurso inestable, cuya tensión interna y silenciosa fisura la cosmovisión y el sistema de valores de los cuales parte el autor como instancia enunciadora forjada en el Centro. Esta tensión, como pudimos advertir, permite la visibilización transitoria de la identidad de los tomochitecos. Enrique Florescano sostiene que "en lugar de una memoria única, en el pasado mexicano [han] existido múltiples memorias, correspondientes a los diversos grupos étnicos, sectores sociales, organizaciones políticas, localidades y entidades regionales" (2010, p. 531). Estas memorias han conseguido sobrevivir porque se afincan en los márgenes del mapa nacional, desde donde se resisten a la homogeneización estatal. Es por este espíritu rebelde que Florescano las llama contramemorias. Pues buen, Tomóchic, tal vez sin pretenderlo, permite que la contramemoria de los tomochitecos -esbozada sutil, tímidamente, como no puede ser de otra manera dado el periodo y las características de quien escribe-logre cierta trascendencia. 
Si bien Tomóchic no deja de ser una típica novela mexicana de finales del siglo XIX, la imagen cuando menos ambigua que ofrece del norte y el norteño -de los que Tomóchic y sus habitantes son una metonimia- es sin duda una anticipación del discurso moderno. A ello contribuye el desplazamiento de Heriberto Frías como sujeto empírico y de Miguel Moderno como sujeto ficcional: el viaje desde Centro a la región septentrional y el posterior contacto con una realidad conocida solo a través de discursos de terceros necesariamente remueve los cimientos y de paso las certidumbres. En ese sentido, Tomóchic puede considerarse antecedente de la novela de la Revolución; es decir, en su ambivalencia de base más que en el aspecto temático: como la de Frías, la obra de Mariano Azuela, Martín Luis Guzmán y Rafael F. Muñoz, por hablar solo de algunos de los nombres más importantes, son fruto de los desplazamientos espaciales, vitales y mentales.

Finalmente, cabe decir que Tomóchic inaugura una tradición -siempre marginal, siempre a la orilla del canon, siempre en la periferia del imaginario nacional- de representaciones culturales legitimadoras del Norte. Como vimos en su momento, el capítulo dedicado a la memoria de Tomóchic, que es una suerte de paréntesis en el decurso "normal" de la obra, le cede la voz a una comunidad desconectada del resto del país, un territorio que no se siente parte de México (Rajchenberg y Héau-Lambert, 2007, p. 54), una patria chica con cultura propia. Pues bien, lo que en Tomóchic es solo un paréntesis después serán obras enteras, como Cartucho (1931) y Las manos de Mamá (1937), de Nellie Campobello, y Crónica de un país bárbaro (1956), de Fernando Jordán, obra citada en la introducción de este trabajo.

\section{Referencias}

Almada, I.; Lorta, J. C.; Contreras, D. y Reyes A. A. (2015). “Casos de despueble de asentamientos atribuidos a apaches en Sonora. Un acercamiento a los efectos de las incursiones apaches en la población de vecinos". En Medina, J. C. y Calderón, E. P. (Coords.), Violencia interétnica en la frontera norte novohispana y mexicana. Siglos XVII-XIX. Hermosillo, Sonora: El Colegio de Sonora.

Alonso, A. M. (1995). Thread of Blood: Colonialism, Revolution, and Gender on Mexico's Northern Frontier. Tuczon, Arizona: University of Arizona Press. 
Barabas, A. M. (2000). "La construcción del indio como bárbaro: de la etnografía al indigenismo." Alteridades, 10(19), 9-20.

Bartra, R. (1992). El salvaje en el espejo. México: ERA.

Cramaussel, C. (2015). "La violencia en el estado de Chihuahua a mediados del siglo XIX. Apaches y comanches". En Medina, J. C. y Calderón, E. P. (Coords.), Violencia interétnica en la frontera norte novohispana y mexicana. Siglos XVII-XIX. Hermosillo, Sonora: El Colegio de Sonora.

Chávez, D. (2006) "Tomóchic: nationalist narrative, homogenizig late nineteenth-century discourse and society in Mexico". Chasqui: Revista de Literatura Latinoamericana, 35(2), 72-88.

Chávez, J. (2007). “De gente ruda a gente sencilla. Símbolo del hombre norteño." En Pérez-Taylor, R.; Olmos, M. y Salas, H. (Eds.), Antropología del desierto: paisaje, naturaleza y sociedad. México: Universidad Nacional Autónoma de México.

Davobe, J. P. (2004). "Tomóchic de Heriberto Frías: violencia campesina, melancolía y genealogía fratricida de las naciones". Revista de Crítica Literaria Latinoamericana, (60), 351-373.

Florescano, E. (2010). Memoria mexicana. Ciudad de México: Fondo de Cultura Económica.

Giménez, G. y Héau-Lambert, C. (2007). "El desierto como territorio, paisaje y referente de identidad." Culturales, 3(5), 7-42.

González, C. y León, R. (2000). Civilizar o exterminar. Tarahumaras y apaches en Chihuahua, siglo XIX. Ciudad de México: Instituto Nacional Indigenista.

Gupta, A. y Ferguson, J. (2008). "Más allá de la 'cultura': espacio, identidad y las políticas de la diferencia". Antípoda. Revista de Antropología y Arqueología, (7), 233-256.

Hall, E. (1989). Inventing the Barbarian: Greek Self-Definition through Tragedy. Oxford: Oxford University Press.

Jordán, F. (1981). Crónica de un país bárbaro. Chihuahua, Chihuahua: Centro Librero La Prensa.

Legrás, H. (2017). Culture and Revolution: Violence, Memory, and the Making of Moderno Mexico. Texas: University of Texas Press.

López, J. (2013). “Monstruosidad y salvajismo: trazas míticas en el marco de la racionalidad griega antigua." Praesentia, (14), 1-21.

Moyano, M. (2001-2002). “La fundación ideológica de las literaturas nacionales. Literatura y territorialización en el siglo XIX argentino". Cuyo Anuario de Filosofía Argentina y Americana, 18(19), 51-61. 
Muñoz, O. M. (2008). "Salvajes, bárbaros y brutos: de la Grecia clásica al México Contemporáneo". Liminar: estudios sociales y humanísticos, 6(2), 155-167.

Nentvig, J. (1971). Descripción geográfica, natural y curiosa de la provincia de Sonora. (Original manuscrito del siglo XVIII). (Ed. Germán Viveros Maldonado). México: Archivo General de la Nación.

Orizaga, D. (2008). "Mediación autorial en Tomóchic, de Heriberto Frías”. Graffylia. Revista de la Facultad de Filosofía y Letras, (6), 197-204.

Rajchenberg, E. y Héau-Lambert, C. (2012). “El desierto como representación del territorio septentrional de México." Antítesis, 5(9), 351-369.

Rajchenberg, E. y Héau-Lambert, C. (2007). "La frontera en la comunidad imaginada del siglo XIX." Frontera Norte, 19(38), 37-61

Rajchenberg, E. y Héau-Lambert, C. (2005). “Las fronteras de la patria." Estudios Sociológicos, 33(67), 239252.

Rajchenberg, E. y Héau-Lambert, C. (2008). "Para una sociología histórica de los espacios periféricos de la nación en América Latina". Antípoda. Revista de Antropología y Arqueología, (7), 175-196.

Raffi-Béroud, C. M. H. (2001). "Heriberto Frías o el escritor en la encrucijada: ¿avenida de la novela o bulevar de la prensa". En Olea, R. (Ed.), Literatura mexicana del otro fin de siglo. México: El Colegio de México.

Sandoval, A. (2001). "Tomóchic de Heriberto Frías a la luz de la Débacle de Émile Zola". En Olea, R. (Ed.), Literatura mexicana del otro fin de siglo. México: El Colegio de México. 